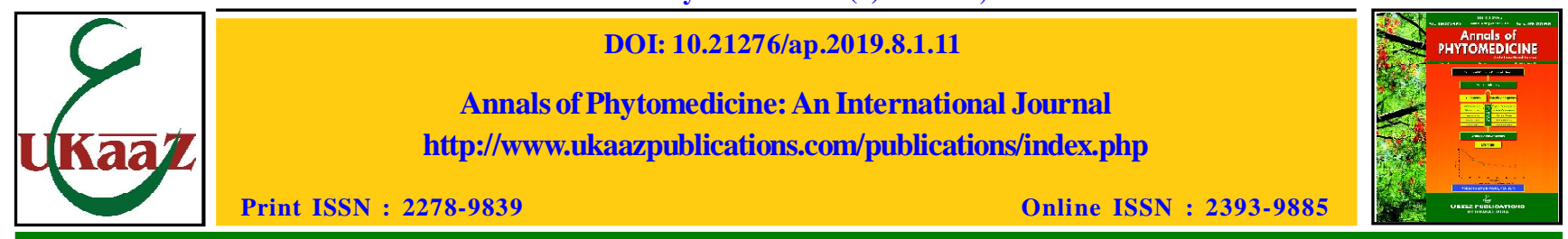

Original article

\title{
Aqueous extract of Viscum angulatum Heyne ex DC inhibits lung metastasis induced by B16F10 melanoma cells in C57BL/6 mice
}

\begin{abstract}
Ramadasan Kuttan and Girija Kuttan
Amala Cancer Research Centre, Amala Nagar, Thrissur-680555, Kerala, India

Received April 9, 2019: Revised May 27, 2019: Accepted May 29, 2019: Published online June 30, 2019

Abstract

The present study is aimed to determine the antimetastatic activity of Viscum angulatum Heyne ex DC extract in C57BL/6 mice after injection B16F10 melanoma cells through lateral tail vein. Metastatic colonies developed in the lungs were counted at $21^{\text {st }}$ day with and without administration of $V$. angulatum extract. This was followed by analysis of biochemical parameters in the lung and serum as well as cytokine expression. In vitro metastasis was studied using Boyden chamber. Administration of extract of $V$. angulatum significantly inhibited the development of lung metastasis in mice as seen for the reduction of metastatic colonies. Biochemical parameters increased in the lung during metastasis such as lung hydroxyproline, hexosamine, uronic acid and serum sialic acid and $\gamma$-glutamyl transpeptidase were reduced by administration of $V$. angulatum extract. Moreover, cytokines levels in the serum such as VEGF, IL2, TIMP, IL6, IL1, GMCSF, IFN $\gamma$ and TNF $\alpha$ which were altered during metastasis were brought back to normal. Expression of cancer related genes which were altered during metastasis such as ERK1, ERK2, NM23, MMP21, MMP9, TIMP1, TIMP2, VEGF were normalized by administration of V. angulatum. This is supported by in vitro invasion studies and histopathological analysis. Results presented indicated the antimetastatic activity of $V$. angulatum extract in C57BL/6 mice.
\end{abstract}

Keywords: Viscum angulatum Heyne ex DC, cancer cell metastasis, melanoma cells, biochemical parameters, serum cytokine levels, cytokine expression.

\section{Introduction}

Metastasis or secondary neoplastic growth is a major step towards malignancy and is a major contributor to cancer mortality (Weigelt et al., 2005). The prognosis of cancer is mainly determined by the invasiveness of the tumor and its ability to metastasize (Ahmad and Hart, 1997). The metastatic process consists of several sequential events including escape of cancer cells from the original tumor (Christofori, 2006), intravasation and dissemination through blood and lymphatic vessels (Hanahan and Folkman, 1996), arrest in the microvasculature of the target organs (Joyce and Pollard, 2009), extravasation and proliferation at a new site (Alitalo et al., 2005). Since basement membrane and extracellular matrix provide the main physical barriers to cancer cell invasion, proteolytic degradation of these structures has been proposed to be important in the metastatic process (Geiger and Peeper, 2009). Any drug which can inhibit one of the steps in the cascade will be useful in the inhibition of tumor metastasis. Although, there are several drugs available to control cancer growth in humans, there are only a few drugs presently available to specifically inhibit the metastasis of cancer cells. This is due to the fact that the cancer cells during metastases may respond differently to radiotherapy or chemotherapy. Understanding the molecular basis of metastasis is crucial for the design and effective use of novel therapeutic strategies to combat metastasis (Steeg, 2006).

\footnotetext{
Author for correspondence: Dr. Ramadasan Kuttan Professor, Amala Cancer Research Centre, Amala Nagar, Thrissur680555, Kerala, India

E-mail: amalacancerresearch@gmail.com

Tel.: +91-9447123071
}

Copyright () 2019 Ukaaz Publications. All rights reserved.

Email: ukaaz@yahoo.com; Website: www.ukaazpublications.com
Use of plants and plant based products in the treatment of cancer has been known for a long time and in fact more than $60 \%$ of the current cancer drugs available in the market are derived from the plant based drugs (Loboda et al., 2005; Polu et al., 2015). Viscum album Linn (European mistletoe) has been extensively studied for its anticancer activity and an injectable preparation; Iscador is being used as an alternate medicine for cancer in many European countries (Leroi, 1975). It is also being used as a complimentary treatment during chemotherapy (Pelzer and Troger, 2018). Active ingredients in V. album have been known which included ML1 and ML2 lectins, polysaccharide, viscotoxin, alkaloids as well as apeptide of 5000 molecular weight. However, much less study has been reported on other Viscum species as most of the species are highly toxic. Recently, we have reported the anticancer and anti-inflammatory activities of six plants in the Family Viscaceae, of which V. angulatum was found to be highly non-toxic and was found to reduce the animal tumors (Kuttan et al., 2017). In the present study, we have checked the antimetastatic activity of $V$. angulatum using in vivo mice models using B16F10 melanoma induced lung cancer models in C57BL/6 mice. Moreover, we have studied its effect in vitro using tumor invasion studies.

\section{Materials and Methods}

\subsection{Animals}

4-6 weeks old male C57BL/6 mice were used in the study. They were purchased from Small Animal Breeding Station attached to Kerala Veterinary and Animal Sciences University, Mannuthy and fed with special mice feed supplied by the breeders and water $a d$ libitum. They were housed in ventilated cages under controlled 
conditions of light and humidity. All the animal experiments were done according to the instructions prescribed by the Committee for the Purpose of Control and Supervision of Experiments on Animals (CPCSEA), Ministry of Environment and Forest, Government of India (Sanction No.149/PO/Rc/S/1999/CPCSEA), and implemented through the Institutional Animal Ethics Committee, Amala Cancer Research Centre (Approval No. ACRC/IAEC/17(6)P1 dated 03.06.2017)

\subsection{Cell lines}

B16F10 melanoma cells were used to induce lung metastases. They were originally procured from National Cell Sciences Centre, Pune and passaged ten times in $\mathrm{C} 57 \mathrm{BL} / 6$ mice to produce highly metastatic B16F10 melanoma cells.

\subsection{Preparation and administration of $V$. angulatum extract}

Viscum angulatum Heyneex DC was originally procured from Western Ghats, near Mysore. Plant was identified and collected by Dr. Shivamurthy G. R, Controller of Examinations, University of Mysore (Voucher No. V.A 23591). Aerial parts were cut into small pieces and washed in running water, it was air dried and powdered. Aqueous extract of the plant was prepared by mixing $10 \mathrm{gm}$ of the plant powder with $100 \mathrm{ml}$ of double distilled water and stirred overnight. Further, it was centrifuged and the supernatant was dried by lyophilization.

\subsection{Determination of the antimetastatic activity in the in vivo system}

C57BL/6 mice were divided into 2 groups ( 8 mice/group) (We have used 8 mice as the experiment was done at one dose only). All the animals were induced tumour metastasis by injecting B16F10 melanoma cells $\left(10^{6}\right.$ cells/ animal) through lateral tail vein. To one group of animals, $V$. angulatum extract was administered at a concentration of $16 \mathrm{mg} / \mathrm{kg}$.b.wt (i.p) for 10 consecutive days. This dose was found to be effective in reducing animal tumours (Kuttan et al., 2017). The other group of animals was kept as untreated metastatic tumor bearing control was treated with vehicle (PBS, pH 7.4) only. Animals from each group were sacrificed on the $21^{\text {st }}$ day after tumor challenge; lungs were excised and blood was collected. Lungs were used for morphological examinations of metastatic tumor nodules and for the estimation of collagen hydroxyproline (Bergman and Loxely, 1970), hexosamine (Elson and Morgan, 1933) and uronic acid (Bitter and Muir, 1962). Serum was separated from the blood and used for the determination of sialic acid (Skoza and Mohos, 1976) and $\gamma$-glutamyl transpeptidase (GGT) (Szasz, 1976) levels. A portion of the serum was used for the estimation of cytokines such as VEGF, TIMP, IL2, IL6, IL1 $\beta$, GMCSF, Interferon $\gamma$ and TNF $\alpha$ using ELISA method using specific antibody coated plates. A portion of the lung was used for the histopathological analysis (Culling, 1976).

\subsection{Determination of the effect of $V$. angulatum on invasion of B16F10 melanoma cells}

The invasion assay was carried out in Boyden chambers. Briefly, the lower compartment of the chamber was filled with serum free DMEM and a polycarbonate filter coated with $25 \mu \mathrm{g}$ Type I collagen. B16F10 melanoma cells $\left(10^{5}\right.$ cells/ $150 \mu$ l DMEM) were then seeded on to the upper chamber. To test the effect of $V$. angulatum on the invasion of B16F10 melanoma cells, different concentrations of the extract (1,2 and $5 \mu \mathrm{g} / \mathrm{ml})$ were added along with the cells to the upper chamber and checked for the number of invasive cells in the lower chamber. The experiment was done in triplicate and the results were expressed as percentage inhibition of invasion (Albini et al., 1987).

2.6 Determination of the effect of $V$. angulatum extract on the expression of k-ras, ERK-1, ERK-2, nm-23, prolyl hydroxylase, lysyl oxidase, MMP-2, MMP-9, TIMP-1, TIMP2 and VEGF

C57BL/6 mice were divided into 2 groups ( 8 mice per group). All the animals were injected with B16F10 melanoma cells $\left(10^{6}\right.$ cells/ animal) through lateral tail vein. Group 1 animals were kept as untreated metastatic tumor bearing control and group 2 animals were treated with $V$. angulatum extract $(16 \mathrm{mg} / \mathrm{kg}$ dose/ animal/ day i.p) for 10 consecutive days. The animals were sacrificed on $21^{\text {st }}$ day. The lungs were excised and RNA was isolated using guanidinethiocyanate (Chomczynski and Sacchi, 1987). The cDNA was prepared by RT-PCR and used for the analysis of expression of k-ras, ERK-1, ERK-2, nm-23, prolyl hydroxylase, lysyl oxidase, MMP-2, MMP-9, TIMP-1, TIMP-2 and VEGF using specific primers. PCR products were analyzed by agarose gel electrophoresis and visualized using gel documentation system.

\subsection{Statistical analysis}

Values are expressed as Mean \pm standard deviation. The statistical significance was compared between control and experimental group by one-way analysis of variance (Anova), followed by appropriate posthoc test (Dunnet multiple comparison test) using Graphpad software. Data of the extract treated animals were compared with non-treated animals.

\section{Results}

\subsection{Effect of $V$. angulatum on the lung tumor nodule formation}

Untreated animals had a massive growth of the tumour and were assigned a number of 250 colonies (Figure 1). Metastatic tumor bearing animals treated with $V$. angulatum showed significant reduction in tumor nodule formation. Simultaneous mode of administration produced maximum effect and showed $85 \%$ reduction in tumor nodules formation. Number of tumour nodules (Table 1) formed was 38.6.

3.2 Effect of $V$. angulatum administration on the biochemical parameters of the metastatic tumour bearing animals

Effect of $V$. angulatum administration on lung and serum biochemical parameters in metastatic tumor bearing animals is shown in Table 2.

\subsubsection{Lung collagen hydroxyproline}

Normal lung had hydroxyproline $1.79 \mu \mathrm{g} / \mathrm{mg}$ protein. Control metastatic tumor bearing animals showed an increased level of lung collagen hydroxyproline $(23.5 \pm 2.81 \mu \mathrm{g} / \mathrm{mg}$ protein $)$, which was significantly reduced to $9.23 \pm 0.63 \mu \mathrm{g} / \mathrm{mg}$ protein in animals treated with $V$. angulatum extract given by the simultaneous mode of administration. 


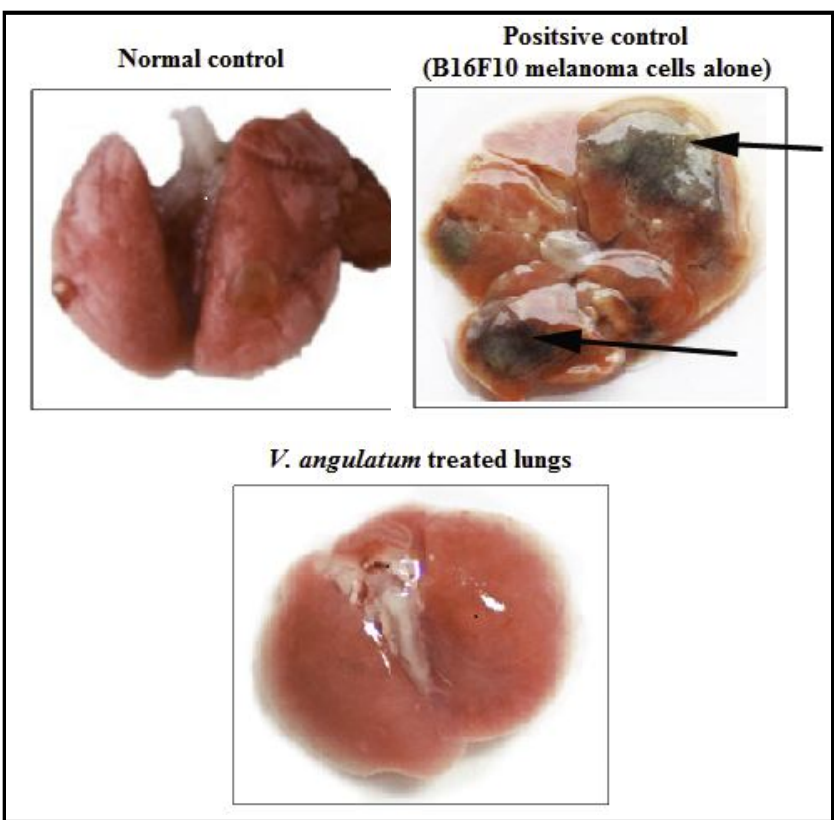

Figure 1: Effect of $V$. angulatum lung colonization of B $16 \mathrm{~F} 10$ melanoma cells. Arrows indicate lung colonies developed.

Table 1: Effect of $V$. angulatum on lung colonization of B $16 \mathrm{~F} 10$ melanoma cells

\begin{tabular}{|l|c|c|}
\hline Treatment & $\begin{array}{c}\text { Number of lung } \\
\text { tumor nodules }\end{array}$ & $\begin{array}{c}\% \text { inhibition of } \\
\text { nodule formation }\end{array}$ \\
\hline $\begin{array}{l}\text { Tumor bearing control } \\
\text { V. angulatum }(500 \mu \mathrm{g} / \\
\text { dose/ animal) } \\
\text { simultaneous }\end{array}$ & $380^{\mathrm{a}}$ & -- \\
\hline
\end{tabular}

Values are average of eight animals.

\subsubsection{Lung hexosamine content}

Lung hexosamine level was highly increased in control metastatic tumor bearing animals $(3.9 \pm 0.12 \mu \mathrm{g} / 100 \mathrm{mg}$ tissue dry wt.) compared to the normal animals $(0.43 \pm 0.03 \mu \mathrm{g} /$ tissue dry wt. $)$. When V. angulatum was administered simultaneously with the tumor cells, this elevated level was reduced to $1.17 \pm 0.1 \mu \mathrm{g} /$ tissue dry weight.

\subsubsection{Uronic acid levels of the lungs}

In control metastatic animals, the lung uronic acid level was drastically elevated $(323.33 \pm 46 \mu \mathrm{g} / 100 \mathrm{mg}$ tissue dry wt.), as compared to normal level $(26.16 \pm 2.4 \mu \mathrm{g} / 100 \mathrm{mg}$ tissue dry wt.) which was significantly reduced after the simultaneous administration of $V$. angulatum $(97.26 \pm 1.53 \mu \mathrm{g} / 100 \mathrm{mg}$ tissue dry wt.).

\subsubsection{Serum sialic acid level}

The serum sialic level of control metastatic tumor bearing animals was highly increased $(128.66 \pm 5.73 \mu \mathrm{g} / \mathrm{ml}$ serum $)$ in tumour bearing animals as compared to normal $(23.33 \pm 1.97 \mu \mathrm{g} / \mathrm{ml}$ serum $)$. Administration of $V$. angulatum extract reduced the level to $58.66 \pm$ $10.41 \mu \mathrm{g} / \mathrm{ml}$ serum.

\subsubsection{Serum $\gamma$-glutamyl transpeptidase (GGT) level}

Highly elevated level of GGT was seen in the serum of control metastatic tumor bearing animals $(108.33 \pm 2.1 \mathrm{n}$ mol P-nitroaniline/ $\mathrm{ml}$ serum) compared to normal animals $(45.82 \pm 4.17 \mathrm{n}$ mol Pnitroaniline/ml serum) which was significantly reduced by the simultaneous mode of administration of $V$. angulatum $(51.83 \pm$ $1.40 \mathrm{n}$ mol P-nitroaniline/ $\mathrm{ml}$ serum).

\subsection{Effect of $V$. angulatum extract on cytokine levels}

Various cytokine levels were measured on $0^{\text {th }}$ day, $7^{\text {th }}$ day and $21^{\text {st }}$ day of metastatic tumor bearing animals with and without treatment with $V$. angulatum extract. Results are shown in Table 3. VEGF was found to be elevated in metastatic tumor bearing animals and the elevated levels were reduced significantly after treatment with $V$. angulatum extract. TIMP was found to be reduced in tumor bearing animals and reduced TIMP was increased by treatment with $V$. angulatum extract. IL2 was found to be lowered and which was brought back to normal after treatment with $V$. angulatum extract. IL6 was found to be significantly elevated in tumor control and elevated levels were reduced by treatment with $V$. angulatum extracts. Similarly, IL1 $\beta$ was elevated in the tumor bearing control and these elevated levels were partially reduced by treatment with Viscum angulatum extract.

Table 2: Effect of $V$. angulatum administration on the biochemical parameters of the metastatic animals

\begin{tabular}{|c|c|c|c|c|}
\hline & Parameters & Normal & Control & Treated \\
\hline \multirow{3}{*}{$\begin{array}{l}\text { Lung } \\
\text { parameters }\end{array}$} & $\begin{array}{l}\text { Hydroxy proline } \\
\text { ( } \mathrm{g} / \mathrm{mg} \text { protein })\end{array}$ & $1.79 \pm 0.10$ & $23.5 \pm 2.81 * * *$ & $9.23 \pm 0.63^{* * *}$ \\
\hline & $\begin{array}{l}\text { Hexosamine } \\
\text { (mg / 100mg tissue } \\
\text { dry weight) }\end{array}$ & $0.43 \pm 0.03$ & $3.9 \pm 0.12 * * *$ & $1.17 \pm 0.10^{* * *}$ \\
\hline & $\begin{array}{l}\text { Uronic acid } \\
(\mu \mathrm{g} / 100 \mathrm{mg} \text { tissue } \\
\text { dry weight })\end{array}$ & $26.16 \pm 2.40$ & $323.33 \pm 8.46^{* * *}$ & $97.26 \pm 1.53$ *** \\
\hline \multirow[t]{2}{*}{$\begin{array}{l}\text { Serum } \\
\text { parameters }\end{array}$} & $\begin{array}{l}\text { Serm sialic acid } \\
(\mu \mathrm{g} / \mathrm{ml})\end{array}$ & $23.33 \pm 1.97$ & $128.66 \pm 5.73 * * *$ & $58.66 \pm 2.98$ *** \\
\hline & $\begin{array}{l}\gamma \text {-GT } \\
\text { (n mol/ P-nitro } \\
\text { aniline/ml serum) }\end{array}$ & $45.83 \pm 4.17$ & $108.33 \pm 2.13 * * *$ & $51.83 \pm 1.46^{* * * *}$ \\
\hline
\end{tabular}

Values are average of eight animals. Values of the control was compared with normal and values of the treated was compared with control $* * *$ highly significant $p<0.001$ 
GMCSF was found to be elevated in tumor bearing animals and elevated GMCSF was reduced by treatment with $V$. angulatum extract. Interferone gamma was significantly reduced in tumor bearing animals and its level was increased by treatment with $V$. angulatum extract. Similarly, TNF- $\alpha$ level was found to be significantly increased in the tumor bearing animals and its level was reduced by treatment with $V$. angulatum extract.

\subsection{Histopathological analysis of lungs}

The haematoxylin and eosin stained sections of lung tissues are shown in Figure 2. The lungs of control metastatic tumor bearing animals showed prominent tumor nodules around terminal bronchiole. These tumor nodules are characterized by polygonal tumor cells with prominent nucleolus, intracellular melanin deposition and clear areas of necrosis. This massive infiltration of the neoplastic cells around the main bronchioles, which make alveolar passages indistinguishable, extended to the pleura. This together with fibrosis reduces alveolar space, which in turn leads to reduced vital capacity. Simultaneous administration of Viscum angulatum showed significant reduction in tumor mass. Alveoli and pleura were tumor free, alveolar passage lined with healthy ciliated columnar epithelial cells and almost similar to normal lung. Considerable reduction of tumor mass also observed in both prophylactic and developed modalities of administration.

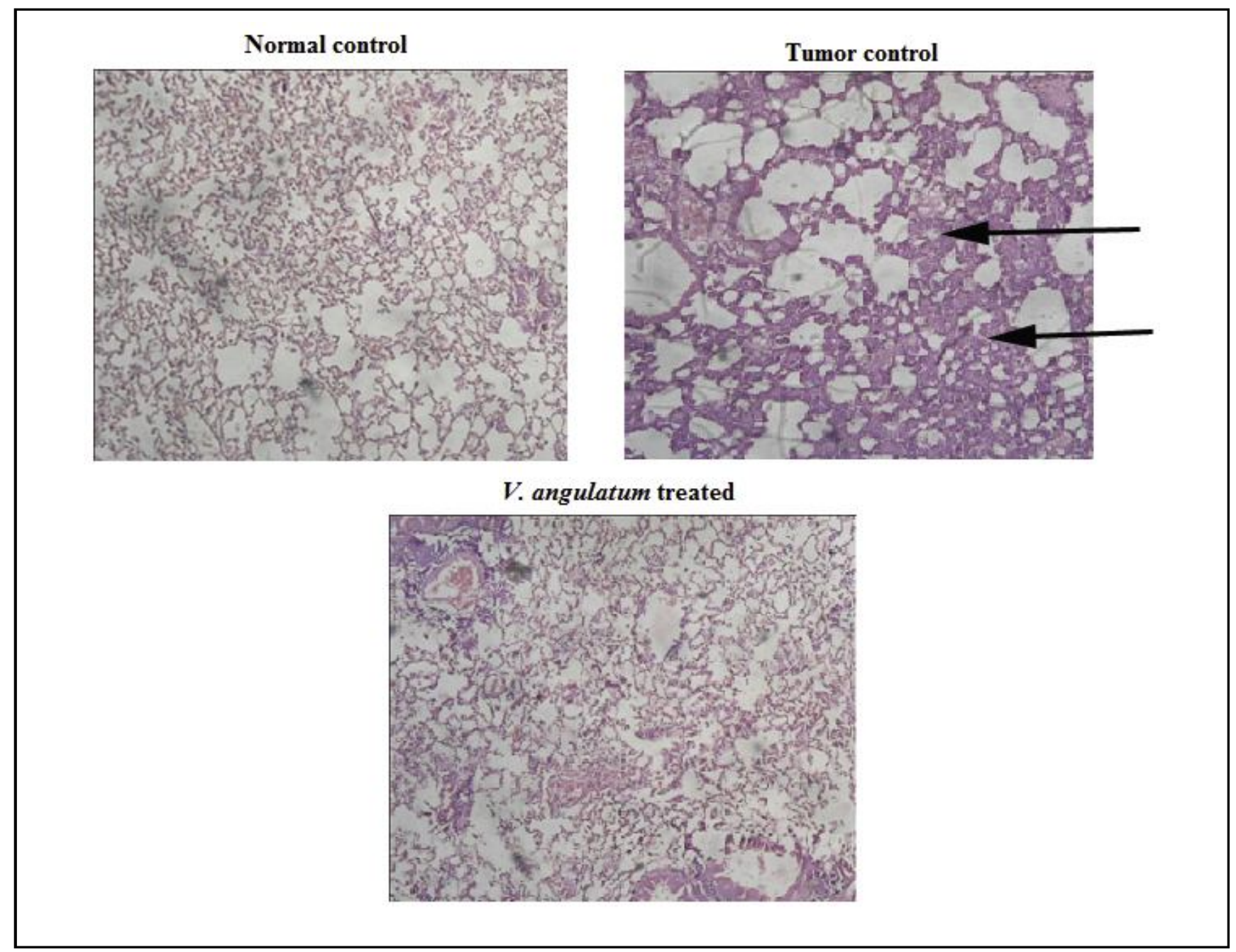

Figure 2: Histopathology of lungs after treatment with $V$. angulatum extract. Arrows indicate tumor cells.

\subsection{Effect of $V$. angulatum on invasion of B16F10 melanoma cells}

Metastatic B16F10 melanoma cells showed high invasive property through the collagen matrix. Large numbers of cells were found in the lower surface of the polycarbonate membrane, but administration of $V$. angulatum produced significant inhibition in the invasion of the collagen matrix by the tumor cells at low concentrations (Figure 3).
3.6 Determination of the effect of $V$. angulatum extract on the expression of k-ras, ERK-1, ERK-2, nm-23, prolyl hydroxylase, lysyl oxidase, MMP-2, MMP-9, TIMP-1, TIMP2 and VEGF

The effect of $V$. angulatum on the expression of genes, ERK-1, ERK-2 is shown in Figure 4. Treatment with V. angulatum significantly down regulated the expression of ERK-1 and ERK-2, which were highly expressed in the lungs of untreated metastatic tumor bearing control animals. 
The effect of $V$. angulatum on the expression of nm-23, prolyl hydroxylase and lysyl oxidase is shown in Figure 4. The tumor suppressor gene nm-23 was highly expressed in the lungs of $V$. angulatum treated metastatic tumor bearing animals whereas in the lungs of untreated metastatic tumor bearing animals; the expression of this gene was highly suppressed. The highly expressed prolyl hydroxylase and lysyl oxidase in the lungs of untreated metastatic tumor bearing animals were significantly suppressed by the administration of $V$. angulatum.
Effect of $V$. angulatum on the expression of genes, MMP-2, MMP9, TIMP-1, TIMP-2 and VEGF is also shown in the Figure 4. Treatment with $V$. angulatum significantly down regulated the expression of MMP-2, MMP-9 and VEGF, which were highly expressed in the lungs of untreated metastatic tumor bearing control animals. Administration of $V$. angulatum significantly upregulated the expression of TIMP-1 and TIMP-2, which was highly suppressed in the lungs of untreated metastatic tumor bearing control animals.

Table 3: Effect of V.angulatum extract on cytokine levels in metastatic animals

\begin{tabular}{|c|c|c|c|c|c|}
\hline \multirow{3}{*}{$\begin{array}{c}\text { Cytokines } \\
\text { (pg/ml) }\end{array}$} & \multicolumn{5}{|c|}{ Cytokine levels after B16F10 induction } \\
\hline & \multirow{2}{*}{$\frac{\mathbf{0}^{\text {th }} \text { day }}{\text { Normal }}$} & \multicolumn{2}{|c|}{$7^{\text {th }}$ day } & \multicolumn{2}{|c|}{$21^{\text {st }}$ day } \\
\hline & & Control & Treated & Control & Treated \\
\hline VEGF & $15.74 \pm 0.87$ & $59.12 \pm 9.28$ & $43.82 \pm 1.48$ & $142.47 * * * \pm 3.77$ & $90.16 \pm 9.53 * * *$ \\
\hline TIMP & $656.18 \pm 9.42$ & $364.98 \pm 9.36$ & $623.99 \pm 8.24$ & $401.78 * * \pm 3.91$ & $635.29 \pm 8.11 * *$ \\
\hline IL-2 & $10.71 \pm 0.46$ & $6.73 \pm 0.43$ & $9.58 \pm 0.32$ & $7.77 * * \pm 0.21$ & $10.83 \pm 0.12 * *$ \\
\hline IL-6 & $34.15 \pm 1.34$ & $342.43 \pm 11.21$ & $281.08 \pm 14.44$ & $436.93 * * * \pm 27.87$ & $331.74 \pm 6.16^{* *}$ \\
\hline $\mathrm{IL}-1 \beta$ & $18.14 \pm 1.67$ & $43.18 \pm 2.65$ & $33.07 \pm 3.16$ & $58.08 * * * \pm 2.94$ & $45.37 \pm 1.35^{* *}$ \\
\hline GMCSF & $18.43 \pm 1.91$ & $37.69 \pm 3.43$ & $25.45 \pm 0.77$ & $42.55^{* * *} \pm 2.13$ & $29.39 \pm 0.98 * *$ \\
\hline IFN- $-\gamma$ & $2562 \pm 60.68$ & $1330 \pm 52.18$ & $2110 \pm 32.48$ & $1510 * * * \pm 56.73$ & $2194 \pm 7.14 * * *$ \\
\hline TNF- $\alpha$ & $21.28 \pm 2.51$ & $352.68 \pm 44.01$ & $236.02 \pm 9.81$ & $346.89 * * * \pm 9.81$ & $277.65 \pm 9.96 * *$ \\
\hline
\end{tabular}

All values are expressed as $\mathrm{pg} / \mathrm{ml}$ of serum. Values are average of eight animals per group. Values of the control were compared with untreated normal animals and values of treated animals were compared with untreated control animals. ${ }^{* * *} p<0.001 * *^{*} p<0.01$.

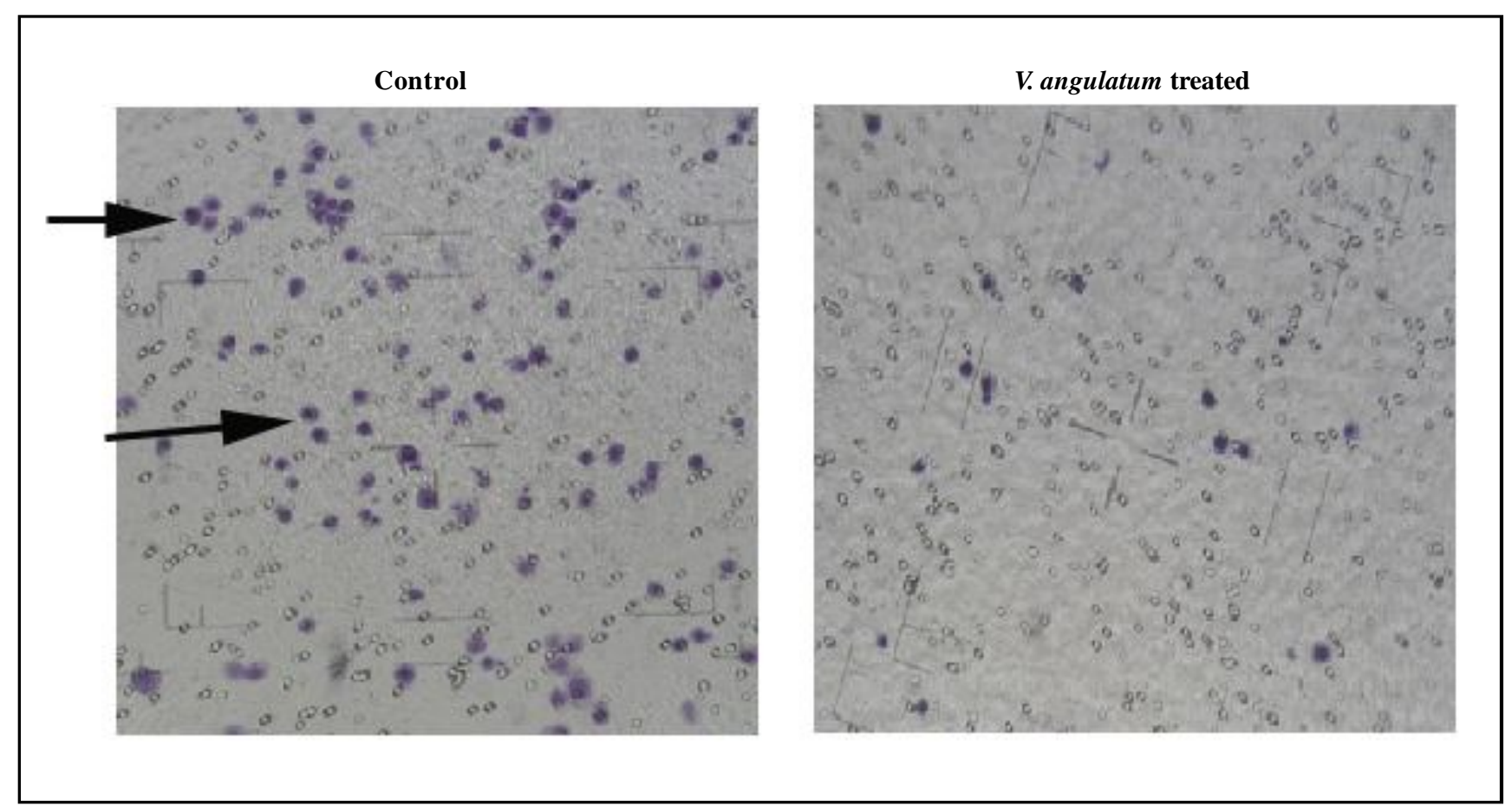

Figure 3: Effect of $V$. angulatum on invasion of $\mathrm{B} 16 \mathrm{~F} 10$ melanomal cells. Arrows indicate invaded tumor cells. 


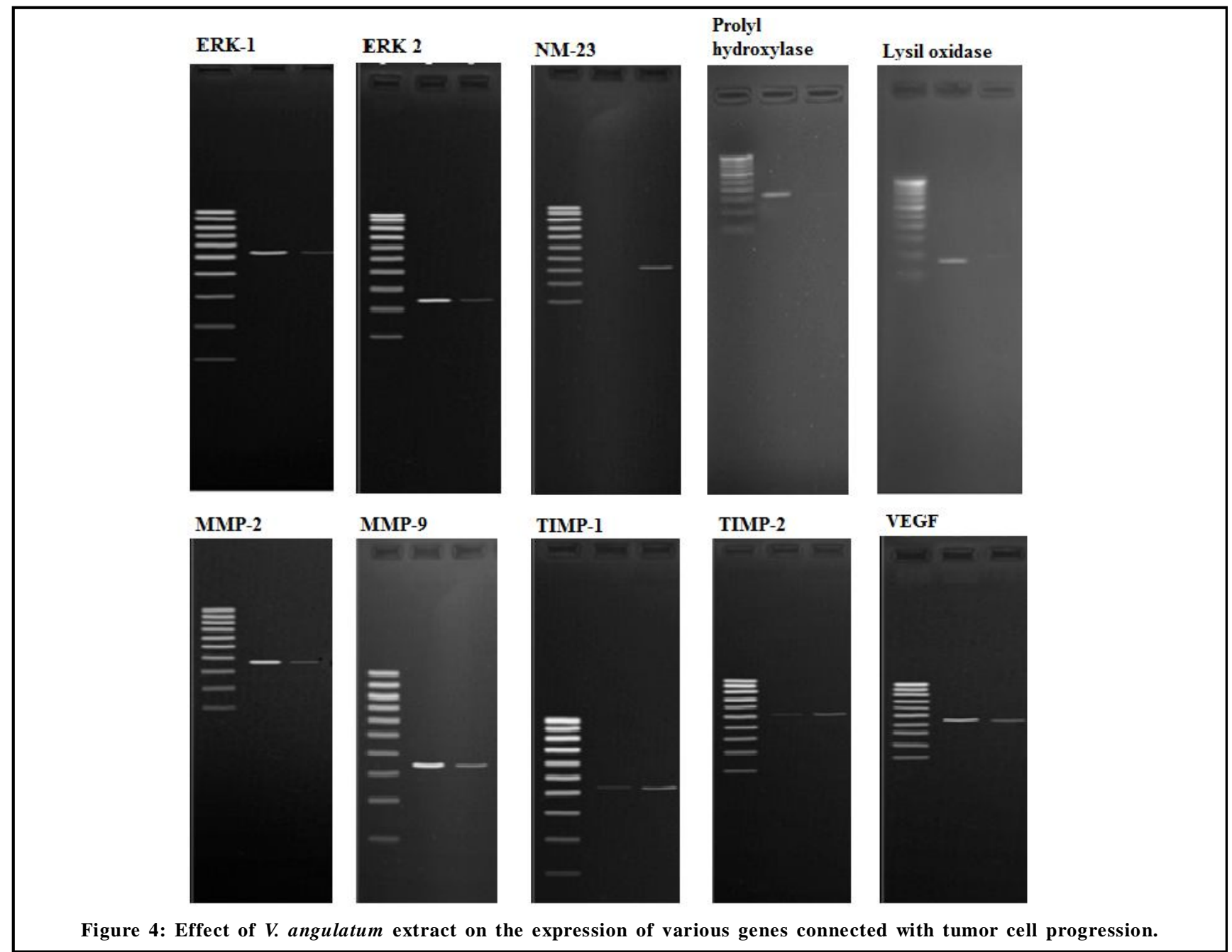

\section{Discussion}

Plants of Viscum species are semiparasitic for which no significant pharmacologic studies have been undertaken and reported excepting for $V$. album. Antitumor and anti-metastatic activity of the $V$. album has been known and an extract made from this plant, Iscador, is being used of cancer treatment in European countries (Leroi, 1975). It has also been reported to have significant immunomodulatory activity (Oei et al., 2019) and, hence useful during cancer therapy. Active compounds of Iscador includes ML1 and ML2 lectins (Franz, 1986), alkaloids (Khwaja et al, 1986), polysaccharides (Jordan and Wagner, 1986), viscotoxins (Samuelson and Petterson, 1971) as well as 5000 molecular weight peptide (Kuttan et al.,1998). Recently, we reported antitumor activity of six Viscum species grown in Western Ghats of India (Kuttan et al., 2017). Out of six plants reported, five plants were found to be highly toxic. $V$. angulatum was found to be non-toxic even at higher concentrations. In this manuscript, we describe the anti-metastatic activity of an herbal extract prepared from the semiparasitic $V$. angulatum using melanoma cells grown in C57BL/6 mice. B16F10 melanoma cells are highly metastatic cells which will produce metastatic colonies in the lungs of C57BL/6 mice. Administration of an aqueous extract of $V$. angulatum was found to significantly inhibit the lung metastasis and biochemical parameters associated with metastasis such as lung hydroxyproline, uronic acid, hexosamine, serum sialic acid and serum- $\gamma$ GT levels which were increased during metastasis was reduced by the administration of $V$. angulatum extract. Hydroxyproline levels indicate the induction of fibrosis while lung hexosamine and uronic acid indicates the collagen deposition, Sialic acid is indicative of deposition of glycosaminoglycans and $\gamma$ glutamyl transpeptidase is an indicator of cellular proliferation. Moreover, many cytokine levels which are indicative of cellular proliferation altered in the serum during metastasis were brought back to normal by the administration of $V$. angulatum extract. The cytokines studied were IL2, IL6,IL1 $\gamma$, VEGF, TIMP, IFN- $\gamma$ and TNF- $\alpha$. This was supported by the expression of several genes involved in the cellular proliferation such as ERK-1, ERK-2, nm23,MMP-2, MMP-9, TIMP-1, TIMP-2, VEGF as well as genes related to prolyl hydroxylase and lysyl oxidase. Altered gene expressions during the metastasis were brought back to normal by the administration of $V$. angulatum extract.

This was further confirmed by histopathological studies. These data clearly indicate that $V$. angulatum extract inhibit the tumor cell metastases as supported by in vitro and in vivo studies. Out of six Viscum species tested in our laboratory, V. angulatum was found to be non-toxic and had significant tumour reducing property. $V$. angulatum has been shown to contain phenolic glycosides (Linn, et 
al., 2002) and flavone glycosides (Asad et al., 2016) which may be responsible for its anticancer and antimetastatic activity. Attenuation of cytokines, oxidative stress and anti-inflammatory activity by phenolic acids have been reported (Yuvaraj et al., 2013). Further, experiments are needed in order to pinpoint the active compound present in this interesting medicinal plant.

\section{Conclusion}

In this study, we have shown the antimetastatic activity of aqueous extract of $V$. angulatum in C57BL/6 mice using B16F10 melanoma cells. Metastatic colonies developed in the mice were significantly reduced by the administration of $V$. angulatum extract. This is supported by biochemical analysis of the lung tissue and serum. Moreover, serum cytokine levels and cytokine expression which were altered during metastasis came back to normal by the administration of $V$. angulatum extract. It was further verified by in vitro invasion studies and histopathological analysis.

\section{Acknowledgements}

This work was financially supported by a grant from National Medicinal Plants Board, Department of AYUSH, Ministry of Health and Family Welfare, Government of India awarded to Girija Kuttan. Authors are thankful to Ms. Liji, M.J. for helping in the preparation of manuscript and Dr. G. R. Shivamurthy for helping in the collection of plants used in this study as well as its identification.

\section{Conflict of interest}

The authors declare that no conflict of interest exists in the course of conducting this research. Both the authors had final decision regarding the manuscript and the decision to submit the findings for publication.

\section{References}

Ahmad, A. and Hart, I.R. (1997). Mechanisms of metastasis. Crit. Rev. Oncol. Hematol., 26:163-173.

Albini, A.; Iwamoto, Y. and Kleinman, H.K. (1987). A rapid in vitro assay for quantitating the invasive potential of tumor cells. Cancer Res., 47:3239-3245.

Alitalo, K.; Tammela, T. and Petrova, T.V. (2005). Lymphangio-genesis in development and human disease. Nature., 438:946-953.

Asad, M.; Santhosh, J. and Agarwal, S. (2016). Isolation and characterization of flavan glycosides from Viscum angulatum B Heyne ex DC.and screening for hypoglycemic activity. Ann. Phytomed., 5:124129.

Bergman, I. and Loxley, R. (1970). The determination of hydroxyproline in urine hydrolysates. Clin. Chem. Acta, 27:347-349.

Bitter, T. and Muir, H.M. (1962). A modified uronic acid carbazole reaction. Anal. Biochem., 4:330-334.

Chomczynski, P. and Sacchi, N. (1987). Single-step method of RNA isolation by acid guanidinium thiocyanate-phenol-chloroform extraction. Anal. Biochem., 162:156-159.

Christofori, G. (2006). New signals from the invasive front. Nature, 441:444-450.

Culling, C.F.A. (1976). Histology. In: Raphael SS (ed) Lynch's. Medical Laboratory Technology, 2:876-1062.
Elson, L.A. and Morgan, W.T. (1933). A colorimetric method for the determination of glucosamine and chondrosamine. Biochem. J., 27:1824-1828

Franz, H. (1986). Mistletoe lectins and A and B chains. Oncol., 43:23-34.

Geiger, T.R. and Peeper, D.S. (2009). Metastasis mechanisms. Biochem. Biophys. Acta, 17(96):293-308.

Hanahan, D. and Folkman, J. (1996). Patterns and emerging mechanisms of the angiogenic switch during tumorigenesis. Cell, 86:353-364.

Jordan, E. and Wagner, H. (1986). Structure and properties of polysaccharide from Viscum album Linn. Oncol., 43:8-15.

Joyce, J.A. and Pollard, J.W. (2009). Microenvironmental regulation of metastasis. Nature Reviews Cancer, 9:239-252.

Khwaja, T.A.; Dias, C.B. and Pentecoast, S. (1986). Recent studies on the anticancer activities of Mistletoe (Viscum album) and its alkaloids. Oncol., 43:42-50.

Kuttan, G; Vasudevan, D.M. and Kuttan, R. (1998). Isolation and identification of a tumor reducing component from mistletoe extract (Iscador). Can. Lett., 66:307-314.

Kuttan, R.; Shivamurthy, G.R. and Kuttan, G. (2017). Potential antitumor and anti-inflammatory activity of six mistletoe plants in the Family Viscaceae present in the Western Ghats, India. International Journal of Pharmacy and Pharmaceutical Sciences, 9:975-1491

Leroi, R. (1975). Clinical experience with mistletoe preparation Iscador: Vittoriq Klostermann. Frankfart, pp:403-414

Linn J.; Chiou, Y. and Lin, Y. (2002). Phenolic glycosides from Viscum angulatum. Journal of Natural Products, 65:638-640.

Loboda, A.; Cisowski, J. and Zarebski, A. (2005). Effects of plant extracts on angiogenic activities of endothelial cells and keratinocytes. J Physiol. Pharmacol., 56:125-137.

Oei, S. L.; Thronicke, A. and Schad, F. (2019). Mistletoe and immunomodulation: insights and implications for anticancer therapies. Evid. Based Compl. and Alt. Med., https://doi.org/10.1155/2019/ 5893017.

Pelszer, F.; Troger, W. and Nat, R. (2018). Complimentary treatment with mistletoe extracts during chemotherapy: safety, neutropenia, fever, and quality of life assessed in a randomized study. J. Alt. and Compl. Medicine, 24:954-961.

Polu, P.; Nayanabhirama, U. and Khan, S. (2015). Herbal medicinal plants as anticancer agents. Ann. Phytomed., 4:37-45.

Samuelson, G. and Petterson, B.M. (1971). The amino acid sequence of Viscotoxin B from European Mistletoe. Europ. J. Biochem., 21: 86-89.

Skoza, L. and Mohos, S. (1976). Stable thiobarbituric acid chromophore with dimethyl sulphoxide: Application to sialic acid assay in analytical de-O-acetylation. Biochem. J., 159:457-462.

Steeg, P.S. (2006). Tumor metastasis: Mechanistic insights and clinical challenges. Nature Med., 12:895-904.

Szasz, G. (1976). Reaction-rate method for gamma-glutamyl transferase activity in serum. Clin. Chem., 22:2051-2055.

Weigelt, B.; Peterse, J.L. and Van't Veer, L,J. (2005). Breast cancer metastasis: markers and models. Nature Rev. Can., 5:591-602.

Yuvaraj, P.; Subramoniam, A.; Louis, T.; Madhavachandran, V. and Narasu, M.L. (2013). Attenuation of expression of cytokines, oxidative stress and inflammation by hepatoprotective phenolic acids from Thespesia populnea Soland ex Correa stem bark. Ann. Phytomed., 2:47-56.

Citation: Ramadasan Kuttan and Girija Kuttan (2019). Aqueous extract of Viscum angulatum Heyne ex DC inhibits lung metastasis induced by B16F10 melanoma cells in C57BL/6 mice. Ann. Phytomed., 8(1):94-100. 